\title{
Prognostic value of circulating vitamin D binding protein, total, free and bioavailable 25-hydroxy vitamin $D$ in patients with colorectal cancer
}

\author{
Lin Yang ${ }^{1, *}$, Hong Chen ${ }^{1, *}$, Miao Zhao ${ }^{1}$ and Peng Peng ${ }^{1}$ \\ ${ }^{1}$ Department of Gastroenterology, Zhongda Hospital, School of Medicine, Southeast University, Nanjing, Jiangsu, China \\ *These authors contributed equally to this work
}

Correspondence to: Hong Chen, email: njchenhong66@163.com

Keywords: VDBP, 25(OH)D, colorectal cancer, prognosis, overall survival

Received: January 04, $2017 \quad$ Accepted: March 13, $2017 \quad$ Published: March 27, 2017

Copyright: Yang et al. This is an open-access article distributed under the terms of the Creative Commons Attribution License 3.0 (CC BY 3.0), which permits unrestricted use, distribution, and reproduction in any medium, provided the original author and source are credited.

\section{ABSTRACT}

Numerous studies have suggested that there was a significantly positive association between circulating total 25-hydroxyvitamin D (25(OH)D) and survival in colorectal cancer patients. Moreover, plasma vitamin D was also found significantly associated with the concentration of vitamin D binding protein (VDBP). However, there was no paper to clarify the prognostic value of VDBP, free and bioavailable $25(\mathrm{OH}) \mathrm{D}$ in colorectal carcinogenesis. The aim of this study was to comprehensively assess the prognostic value of VDBP, total, free and bioavailable 25(OH)D in stage I-III colorectal cancer patients. A total of 206 colorectal cancer patients were enrolled in this prospective study. Preoperative plasma total 25(OH)D and VDBP concentrations were measured by direct enzyme-linked immunosorbent assay, and albumin concentration was measured by Beckman automatic biochemical analyzer. Free and bioavailable 25(OH)D concentrations were calculated based on the concentrations of plasma VDBP, total 25(OH) D and albumin. X-title program was used to determine the optimal cut-off values of VDBP, total, free and bioavailable 25(OH)D. Results showed that elevated free and bioavailable 25(OH)D were significantly associated with better 5-year overall survival (OS) by univariate analysis. By multivariate cox analysis, we also found that the high level of free 25(OH)D ( $\mathrm{HR}=0.442,95 \% \mathrm{CI}=0.238-0.819, P<0.010)$ could be identified as an independent factor for better OS. In conclusion, our study suggested that higher levels of free and bioavailable $25(\mathrm{OH}) \mathrm{D}$ were associated with better OS in stage I-III colorectal cancer patients. Moreover, free 25(OH)D could be considered as an independent prognostic biomarker for OS.

\section{INTRODUCTION}

Colorectal cancer (CRC) is the third prevalent cancer and the fourth most common cause of cancerrelated mortality worldwide [1]. In China, about 376.3 thousands people were diagnosed as $\mathrm{CRC}$ and about 191.0 thousands patients were died of CRC annually [2]. With the development of technology of diagnosis and treatment, many patients could be treated at the early stage of the disease, but the mortality of CRC was still increasing. Numerous studies have shown that high level of circulating vitamin $\mathrm{D}$ was associated with decreased CRC risk [3-7], suggesting a protective role of vitamin
D against CRC. Although vitamin D can obtain from diet and even dietary supplements, most vitamin $\mathrm{D}$ is photochemically synthesized in the skin exposed to sunlight [8]. Unfortunately, due to changing of lifestyle and environment, reduced outdoor activity and the absence of adequate sun exposure, vitamin D deficiency becomes a common phenomenon both in healthy individuals and in CRC populations [9].

Vitamin D, a kind of trace elements, exists with two major kinds of formations, 25-hydroxy vitamin $\mathrm{D}(25(\mathrm{OH})$ $\mathrm{D}$,) and 1,25-dihydroxy vitamin $\mathrm{D}_{3}\left(1,25(\mathrm{OH})_{2} \mathrm{D}_{3}\right)$. Particularly, $25(\mathrm{OH}) \mathrm{D}$, is the major circulating form of vitamin $\mathrm{D}[10]$, thus, the total serum $25(\mathrm{OH}) \mathrm{D}$ level is 
considered to be the best indicator of vitamin $\mathrm{D}$ [11]. Transported from liver to circulation, $25(\mathrm{OH}) \mathrm{D}$ is bound primarily to vitamin D binding protein (VDBP) and albumin, and a very small fraction remains free or unbound [12]. The latter is called as free 25(OH)D. Besides, albumin shows a weaker affinity to $25(\mathrm{OH}) \mathrm{D}$ than that of VDBP, thus, $25(\mathrm{OH}) \mathrm{D}$ can easily dissociate from the albumin [13]. Therefore, both free and albumin bound $25(\mathrm{OH}) \mathrm{D}$ can bind to vitamin $\mathrm{D}$ receptor (VDR) easily in the surface of target tissues and exert biological effects. As a result, free and albumin bound $25(\mathrm{OH}) \mathrm{D}$ are regarded as the bioavailable $25(\mathrm{OH}) \mathrm{D}$. On the other hand, VDR is expressed both in normal cells and in malignant dividing cells[14], and is related to cell proliferation, differentiation, invasion and angiogenesis [15]. Moreover, VDBP is a multifunctional protein that belongs to the albumin gene family and is the precursor to the immunemodulatory protein[16], Gc protein-derived macrophage activating factor (Gc-MAF), which is a Macrophage Activating Factor (MAF) that can activate macrophage against cancer cell [17]. Hence, we speculated that the concentrations of peripheral blood vitamin D and VDBP were associated with the survival in patients with CRC.

Recently, several studies reported that $25(\mathrm{OH}) \mathrm{D}$ was associated with the risk of CRC [18-20], and VDBP was not associated with the risk of various cancers, including CRC [21]. However, VDBP was found significantly associated with the concentration of plasma vitamin D [22, 23]. Recently, Ying et al. demonstrated that there was no direct association between VDBP and the risk of CRC. And they also found low level of $25(\mathrm{OH}) \mathrm{D}$ was associated with the risk of CRC only when circulating VDBP was below the median level [24]. These results indicated that it might be better to combine $25(\mathrm{OH}) \mathrm{D}$ and VDBP together for describing the relationship between vitamin D and CRC. Furthermore, two studies have shown an association between low level of total $25(\mathrm{OH}) \mathrm{D}$ and poor CRC survival outcome $[3,8]$. Unfortunately, all of these studies didn't further explore the prognostic value of free, bioavailable $25(\mathrm{OH}) \mathrm{D}$ and VDBP in CRC patients. Hence, in this study, we aimed to comprehensively assess the prognostic value of VDBP, total, free and bioavailable $25(\mathrm{OH}) \mathrm{D}$ in stage I-III CRC patients.

\section{RESULTS}

\section{The optimal cut-off values of plasma VDBP, total, free and bioavailable 25(OH)D}

The patients were categorized into three tertiles based on the VDBP, total, free and bioavailable $25(\mathrm{OH}) \mathrm{D}$ determined by $\mathrm{X}$-title program (Figure 1). The VDBP tertiles obtained from our data include the low VDBP tertile group (VDBP $<159.2$ $\mathrm{ug} / \mathrm{ml})$, middle VDBP tertile (VDBP $=159.2-310.1 \mathrm{ug} / \mathrm{ml})$, the high VDBP tertile (VDBP > 310.1ug/ml). Likewise, total, free and bioavailable $25(\mathrm{OH}) \mathrm{D}$ tertiles also included low, middle and high tertile groups, which were listed in Table 1.

\section{Baseline characteristics of enrolled participants}

The baseline characteristics of CRC patients were summarized in Table 2. A total of 206 CRC patients with 131 males and 75 females were enrolled in this study. They had a median age of 63 years (range from 30 to 85). Of them, no smoking, no drinking, no diabetes and no hypertension were all in the majority. Colon was the most common location site of the tumor $(n=112)$. A total of $125(60.7 \%)$ patients were in stage III, and according to local histopathology grading, $155(75.2 \%)$ patients were found in moderate cell differentiation. All patients underwent surgery and $151(73.3 \%)$ patients received chemotherapy. During follow-up period, 87 patients (42.2\%) died by the date of the recently scheduled followup, the median follow-up time was 45 months.

\section{The association between baseline characteristics and clinical prognosis}

The association between baseline characteristics and overall survival (OS) in CRC patients were listed in Table 3. In Kaplan-Meier and univariate analysis, our results showed that age ( $<63$ years), no smoking, body mass index (BMI) $\left(<22.16 \mathrm{~kg} / \mathrm{m}^{2}\right)$, no hypertension, no diabetes, TNM stage (I-II), high cell differentiation, albumin $(>35 \mathrm{~g} / \mathrm{l})$, middle and high group of free and bioavailable $25(\mathrm{OH})$ $\mathrm{D}$ were significantly associated with better $\mathrm{OS}\left(P_{\text {all }}<0.05\right.$; Figure 1 and Table 3). Clinical baseline characteristics for the prediction of clinical prognosis were further investigated by multivariate analysis with Cox regression model. Smoking $(\mathrm{HR}=1.841,95 \% \mathrm{CI}=1.149-2.949$, $P=0.011)$, BMI $\left(>22.16 \mathrm{~kg} / \mathrm{m}^{2}\right) \quad(\mathrm{HR}=2.004$, $95 \% \mathrm{CI}=1.244-3.228, P=0.004)$, low cell differentiation $(\mathrm{HR}=3.912,95 \% \mathrm{CI}=1.130-13.551, P=0.031)$, albumin $(>35 \mathrm{~g} / \mathrm{l})(\mathrm{HR}=0.590,95 \% \mathrm{CI}=0.383-0.909$, $P=0.017)$ were still associated with clinical prognosis. More importantly, comparing patients in the high group and middle group versus the low group of free $25(\mathrm{OH})$ $\mathrm{D}$, the adjusted hazard ratio (HR) was $0.442(95 \% \mathrm{CI}=$ $0.238-0.819, P=0.010)$ and $0.241(95 \% \mathrm{CI}=0.117-0.495$, $P<0.001)$ for OS, respectively. Our results indicated that middle and high group of free $25(\mathrm{OH}) \mathrm{D}$, no smoking, BMI $\left(<22.16 \mathrm{~kg} / \mathrm{m}^{2}\right)$, high cell differentiation, albumin $(>35$ $\mathrm{g} / \mathrm{l})$ could be considered to be independent markers for better OS of CRC patients.

\section{DISCUSSION}

In this study, we found that low levels of free and bioavailable $25(\mathrm{OH}) \mathrm{D}$ were both associated with poor OS, and free $25(\mathrm{OH}) \mathrm{D}$ was an independent prognostic factor for OS. To the best of our knowledge, this might be the first research which explored the association of plasma VDBP, total, free and bioavailable $25(\mathrm{OH}) \mathrm{D}$ with the prognosis of patients with stage I-III CRC at the same time. 
Table 1: The cut-off values of plasma VDBP, total, free and bioavailable 25(OH)D

\begin{tabular}{lccc}
\hline Group & Low group & Middle group & High group \\
\hline VDBP $(\mathrm{ug} / \mathrm{ml})$ & $<159.2$ & $159.2-310.1$ & $>310.1$ \\
Total 25(OH)D $(\mathrm{ng} / \mathrm{ml})$ & $<6.2$ & $6.2-29.9$ & $>29.9$ \\
Free 25(OH)D $(\mathrm{pg} / \mathrm{ml})$ & $<0.01$ & $0.01-0.02$ & $>0.02$ \\
Bioavailable 25(OH)D $(\mathrm{ng} / \mathrm{ml})$ & $<0.58$ & $0.58-1.03$ & $>1.03$ \\
\hline
\end{tabular}

Abbreviations: 25(OH)D: 25-hydroxyvitamin D; VDBP: vitamin D binding protein.

This study indicated that low levels of free and bioavailable $25(\mathrm{OH}) \mathrm{D}$ were both associated with poor OS, which indicated that free and bioavailable $25(\mathrm{OH}) \mathrm{D}$ had a protective effect from death for CRC patients and had utility as biomarkers for survival monitoring. However, previous studies reported that total $25(\mathrm{OH}) \mathrm{D}$ was also associated with the survival of CRC $[3,8]$, which was inconsistent with our study. Maybe this phenomenon could be explained by the number of patients from different tumor stages and different geographic regions. Therefore, further study with larger samples should be applied to confirm this result. Furthermore, different cut-off values determined by different tools could also contribute to this difference. In this study, $\mathrm{X}$-tile program, a robust graphical tool verified by Yale
University was used by us to determine the optimum cutoff values. Our study demonstrated that circulating VDBP was not associated with the survival of CRC patients, which was consistent with the recent study by Ying et al. [24]. Theoretically, free and bioavailable $25(\mathrm{OH}) \mathrm{D}$ would be more representative for the function of vitamin $\mathrm{D}$ than total $25(\mathrm{OH}) \mathrm{D}$ because only free $25(\mathrm{OH}) \mathrm{D}$ could bind to VDR and play an important role in biological activity [25].

The following mechanisms might explain our results. Almost all CRC patients had abnormal $\beta$-catenin signal transduction pathway[26] and 25(OH)D in colon and several other tissues could be converted into hormonally active $1,25(\mathrm{OH})_{2} \mathrm{D}_{3}$ which could inhibit the abnormal signal pathway, and promote the differentiation of tumor cells
A
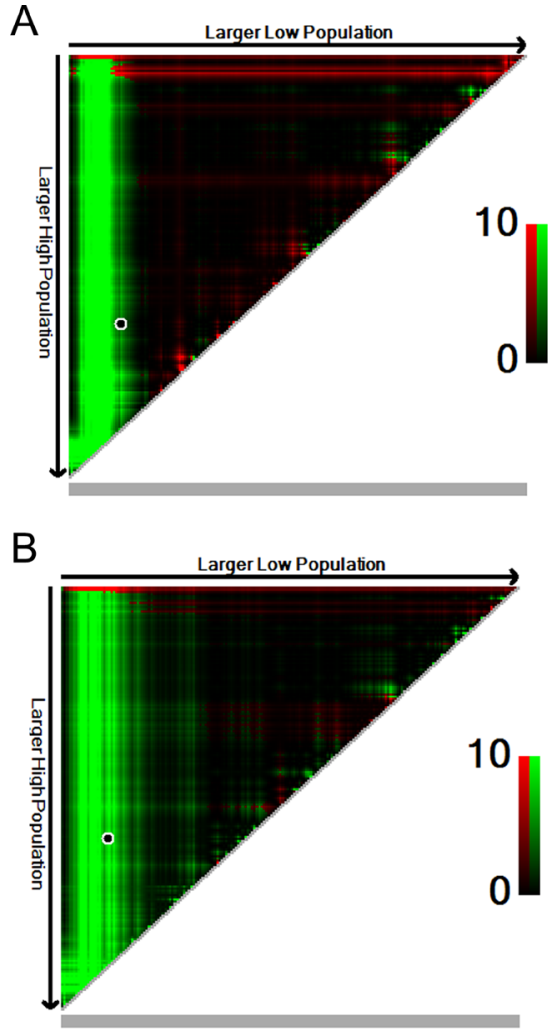
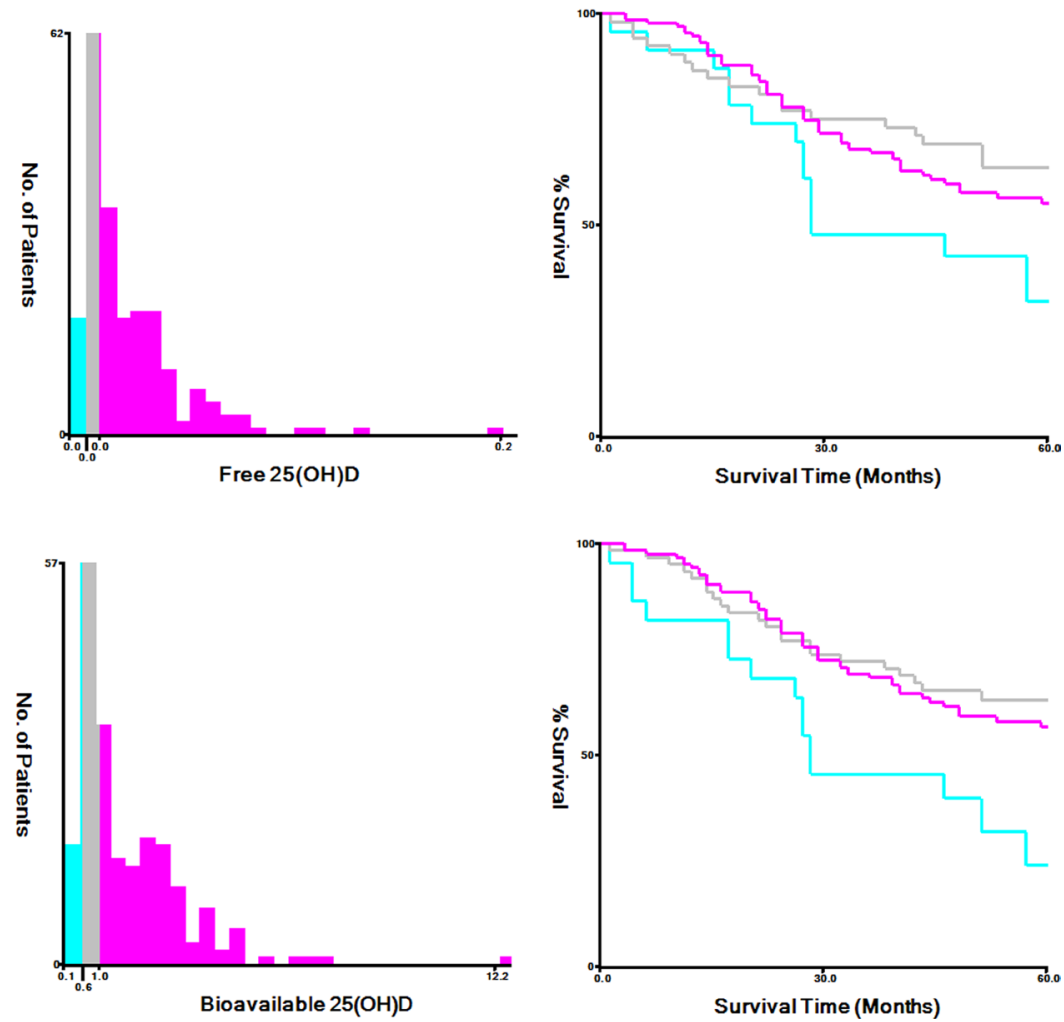

Figure 1: X-tile analyses for 5-year overall survival. The sample of CRC patients was equally divided into training and validation sets. X-tile plots of training sets were shown in the left panels, with plots of matched validation sets shown in the smaller inset. The optimal cut-off values highlighted by the black circles in left rectangular panels were also shown in histograms of the entire cohort (middle panels), and Kaplan-Meier plots were displayed in right panels. $p$ values were determined by using the cut-off values defined in training sets and applying them to validation sets. The optimal cut-off values of Free $25(\mathrm{OH}) \mathrm{D}$ and Bioavailable $25(\mathrm{OH}) \mathrm{D}$ for OS were $0.01-0.01 \mathrm{pg} / \mathrm{ml}$, and 0.58-1.03 ng/ml, respectively. (A) Free 25(OH)D. (B) Bioavailable 25(OH)D. CRC, colorectal cancer; VDBP, vitamin D binding protein; OS, overall survival. 
Table 2: The baseline characteristics of patients with colorectal cancer

\begin{tabular}{|c|c|c|c|c|c|c|c|c|c|c|c|c|c|c|c|c|c|}
\hline \multirow[b]{2}{*}{ Parameters } & \multirow[b]{2}{*}{$\begin{array}{c}\text { Total patients } \\
\qquad N=206\end{array}$} & \multicolumn{4}{|c|}{ VDBP } & \multicolumn{4}{|c|}{ Total 25(OH)D } & \multicolumn{4}{|c|}{ Free 25(OH)D } & \multicolumn{4}{|c|}{ Bioavailable 25(OH)D } \\
\hline & & $\begin{array}{c}\text { Low } \\
N=40\end{array}$ & $\begin{array}{l}\text { Middle } \\
N=145\end{array}$ & $\begin{array}{l}\text { High } \\
N=21\end{array}$ & $P^{*}$ & $\begin{array}{c}\text { Low } \\
N=\mathbf{5 9}\end{array}$ & $\begin{array}{l}\text { Middle } \\
N=123\end{array}$ & $\begin{array}{c}\text { High } \\
N=\mathbf{2 4}\end{array}$ & $P^{*}$ & $\begin{array}{c}\text { Low } \\
N=19\end{array}$ & $\begin{array}{l}\text { Middle } \\
N=72\end{array}$ & $\begin{array}{l}\text { High } \\
115\end{array}$ & $P^{*}$ & $\begin{array}{c}\text { Low } \\
N=21\end{array}$ & $\begin{array}{l}\text { Middle } \\
N=61\end{array}$ & $\begin{array}{c}\text { High } \\
N=124\end{array}$ & $P^{*}$ \\
\hline Age(years) & & & & & 0.037 & & & & 0.116 & & & & 0.555 & & & & 0.68 \\
\hline$>63$ & 110 & 25 & 79 & 6 & & 38 & 59 & 13 & & 9 & 42 & 59 & & 13 & 31 & 66 & \\
\hline$<63$ & 96 & 15 & 66 & 15 & & 21 & 64 & 11 & & 10 & 30 & 56 & & 8 & 30 & 58 & \\
\hline Gender & & & & & 0.57 & & & & 0.07 & & & & 0.061 & & & & 0.023 \\
\hline Male & 131 & 28 & 91 & 12 & & 44 & 75 & 12 & & 14 & 52 & 65 & & 14 & 47 & 70 & \\
\hline Female & 75 & 12 & 54 & 9 & & 15 & 48 & 12 & & 5 & 20 & 50 & & 7 & 14 & 54 & \\
\hline Smoking & & & & & 0.402 & & & & 0.055 & & & & 0.247 & & & & 0.324 \\
\hline Yes & 49 & 8 & 38 & 3 & & 15 & 33 & 1 & & 4 & 22 & 23 & & 6 & 18 & 25 & \\
\hline No & 157 & 32 & 107 & 18 & & 44 & 90 & 23 & & 15 & 50 & 92 & & 15 & 43 & 99 & \\
\hline Drinking & & & & & 0.321 & & & & 0.371 & & & & 0.401 & & & & 0.89 \\
\hline Yes & 24 & 3 & 20 & 1 & & 6 & 17 & 1 & & 1 & 11 & 12 & & 2 & 8 & 14 & \\
\hline No & 182 & 37 & 125 & 20 & & 53 & 106 & 23 & & 18 & 61 & 103 & & 19 & 53 & 110 & \\
\hline $\operatorname{BMI}\left(\mathbf{k g} / \mathbf{m}^{2}\right)$ & & & & & 0.01 & & & & 0.183 & & & & 0.215 & & & & 0.508 \\
\hline$<22.16$ & 103 & 28 & 63 & 12 & & 34 & 55 & 14 & & 13 & 33 & 57 & & 12 & 27 & 64 & \\
\hline$>22.16$ & 103 & 12 & 82 & 9 & & 25 & 68 & 10 & & 6 & 39 & 58 & & 9 & 34 & 60 & \\
\hline Hypertension & & & & & 0.228 & & & & 0.946 & & & & 0.215 & & & & 0.12 \\
\hline Yes & 46 & 5 & 35 & 6 & & 13 & 27 & 6 & & 3 & 21 & 22 & & 5 & 19 & 22 & \\
\hline No & 160 & 35 & 110 & 15 & & 46 & 96 & 18 & & 16 & 51 & 93 & & 16 & 42 & 102 & \\
\hline Diabetes & & & & & 0.487 & & & & 0.156 & & & & 0.056 & & & & 0 \\
\hline Yes & 30 & 8 & 20 & 2 & & 13 & 14 & 3 & & 5 & 14 & 11 & & 10 & 9 & 11 & \\
\hline No & 176 & 32 & 125 & 19 & & 46 & 109 & 21 & & 14 & 58 & 104 & & 11 & 52 & 113 & \\
\hline TMN stage & & & & & 0.643 & & & & 0.311 & & & & 0.962 & & & & 0.821 \\
\hline I-II & 81 & 18 & 56 & 7 & & 24 & 51 & 6 & & 7 & 29 & 45 & & 8 & 26 & 47 & \\
\hline III & 125 & 22 & 89 & 14 & & 35 & 72 & 18 & & 12 & 43 & 70 & & 13 & 35 & 77 & \\
\hline Cell differentia & ation & & & & 0.937 & & & & 0.195 & & & & 0.86 & & & & 0.665 \\
\hline $\mathrm{H}$ & 20 & 4 & 16 & 0 & & 8 & 10 & 2 & & 3 & 9 & 8 & & 2 & 7 & 11 & \\
\hline M & 155 & 30 & 106 & 19 & & 39 & 101 & 15 & & 13 & 49 & 93 & & 14 & 44 & 97 & \\
\hline $\mathrm{L}$ & 31 & 6 & 23 & 2 & & 12 & 12 & 7 & & 3 & 14 & 14 & & 5 & 10 & 16 & \\
\hline Location & & & & & 0.02 & & & & 0.206 & & & & 0.008 & & & & 0.049 \\
\hline Colon & 112 & 16 & 88 & 8 & & 27 & 73 & 12 & & 5 & 47 & 60 & & 7 & 39 & 66 & \\
\hline Rectal & 94 & 24 & 57 & 13 & & 32 & 50 & 12 & & 14 & 25 & 55 & & 14 & 22 & 58 & \\
\hline Chem & & & & & 0.205 & & & & 0.605 & & & & 0.818 & & & & 0.06 \\
\hline Yes & 151 & 33 & 105 & 13 & & 42 & 93 & 16 & & 13 & 52 & 86 & & 11 & 48 & 92 & \\
\hline No & 55 & 7 & 40 & 8 & & 17 & 30 & 8 & & 6 & 20 & 29 & & 10 & 13 & 32 & \\
\hline Albumin (g/l) & & & & & 0.003 & & & & 0.097 & & & & 0.136 & & & & 0.025 \\
\hline$<35$ & 69 & 11 & 44 & 14 & & 15 & 42 & 12 & & 6 & 18 & 45 & & 12 & 15 & 42 & \\
\hline$>35$ & 137 & 29 & 101 & 7 & & 44 & 81 & 12 & & 13 & 54 & 70 & & 9 & 46 & 82 & \\
\hline Death & & & & & 0.177 & & & & 0.371 & & & & 0.013 & & & & 0.047 \\
\hline Yes & 87 & 13 & 62 & 12 & & 22 & 52 & 13 & & 13 & 23 & 51 & & 14 & 22 & 51 & \\
\hline No & 119 & 27 & 83 & 9 & & 37 & 71 & 11 & & 6 & 49 & 64 & & 7 & 39 & 73 & \\
\hline
\end{tabular}

Abbreviations: 25(OH)D: 25-hydroxyvitamin D; VDBP: vitamin D binding protein; BMI: body mass index; Chem: Chemotherapy; H: high cell differentiation; M: moderate cell differentiation; L: low cell differentiation.

Note: The bold represent that $P$ value was statistically significant.* Difference between groups was tested by Chi-square test.

by stimulating $\beta$-catenin-TCF-4 target gene $[27,28]$ and inducing E-cadherin [29, 30] Furthermore, the $1,25(\mathrm{OH})_{2} \mathrm{D}_{3}$ had direct anti-tumor effect [31] because several oncogenes or anti-oncogenes could be regulated by vitamin $\mathrm{D}$ [32], such as TGF- $\beta$, TNF- $\alpha$, p27/Kip1, c-myc, c-fos, c-jun, which were closely associated with the proliferation and differentiation of some specific cells [33]. Some previous studies indicated that TGF- $\beta$, which could inhibit the growth of enterocytes, could be antagonized by CRC cells[34], and this resulted in the growth of CRC tissues. However, this process could be interdicted by $1,25(\mathrm{OH})_{2} \mathrm{D}_{3}$ through increasing the activity of TGF- $\beta$ on CRC cells [35]. In addition, $1,25(\mathrm{OH})_{2} \mathrm{D}_{3}$ could 
Table 3: COX regresion based on overall survival

\begin{tabular}{|c|c|c|c|c|c|c|c|}
\hline \multirow[b]{2}{*}{ Parameters } & \multirow{2}{*}{$\begin{array}{c}\text { Total patients } \\
N=206\end{array}$} & \multirow{2}{*}{$\frac{5 \text {-year OS }}{\text { NUM of death }}$} & \multirow[t]{2}{*}{ Log-rank $P$ value } & \multicolumn{2}{|c|}{ univariate analysis } & \multicolumn{2}{|c|}{ multivariate analysis } \\
\hline & & & & HR(95\%CI) & $P$-value & HR(95\%CI) & $P$-value \\
\hline Age(years) & & & 0.047 & & & & \\
\hline$<63$ & 96 & 49 & & Reference & & Reference & \\
\hline$>63$ & 110 & 38 & & $1.528(1.000,2.334)$ & 0.05 & $1.237(0.766,1.999)$ & 0.385 \\
\hline Gender & & & 0.921 & & & & \\
\hline Male & 131 & 56 & & Reference & & & \\
\hline Female & 75 & 31 & & $0.978(0.631,1.517)$ & 0.922 & & \\
\hline Smoking & & & 0.03 & & & & \\
\hline No & 157 & 59 & & Reference & & Reference & \\
\hline Yes & 49 & 28 & & $1.631(1.040,2.558)$ & 0.033 & $1.841(1.149,2.949)$ & 0.011 \\
\hline Drinking & & & 0.555 & & & & \\
\hline No & 182 & 75 & & Reference & & & \\
\hline Yes & 24 & 12 & & $1.199(0.652,2.206)$ & 0.559 & & \\
\hline BMI $\left(\mathrm{kg} / \mathrm{m}^{2}\right)$ & & & 0.008 & & & & \\
\hline$<22.16$ & 103 & 34 & & Reference & & Reference & \\
\hline$>22.16$ & 103 & 53 & & $1.778(1.155,2.736)$ & 0.009 & $2.004(1.244,3.228)$ & 0.004 \\
\hline Hypertension & & & 0.011 & & & & \\
\hline No & 160 & 60 & & Reference & & Reference & \\
\hline Yes & 46 & 27 & & $1.787(1.134,2.816)$ & 0.012 & $1.544(0.959,2.486)$ & 0.074 \\
\hline Diabetes & & & 0.005 & & & & \\
\hline No & 176 & 68 & & Reference & & Reference & \\
\hline Yes & 30 & 19 & & $2.035(1.222,3.388)$ & 0.006 & $1.403(0.763,2.581)$ & 0.276 \\
\hline TMN stage & & & 0.038 & & & & \\
\hline I-II & 81 & 26 & & Reference & & Reference & \\
\hline III & 125 & 61 & & $1.613(1.018,2.556)$ & 0.042 & $1.147(0.900,1.463)$ & 0.267 \\
\hline Cell differentia & tion & & 0.03 & & & & \\
\hline $\mathrm{H}$ & 20 & 3 & & Reference & & Reference & \\
\hline M & 155 & 67 & & 3.584(1.127,11.397) & 0.031 & $2.281(0.699,7.442)$ & 0.172 \\
\hline $\mathrm{L}$ & 31 & 17 & & $4.662(1.365,15.914)$ & 0.014 & $3.912(1.130,13.551)$ & 0.031 \\
\hline Location & & & 0.569 & & & & \\
\hline Rectal & 94 & 41 & & Reference & & & \\
\hline Colon & 112 & 46 & & $0.886(0.581,1.350)$ & 0.572 & & \\
\hline Chem & & & 0.365 & & & & \\
\hline No & 55 & 20 & & Reference & & & \\
\hline Yes & 151 & 67 & & $1.257(0.763,2.073)$ & 0.37 & & \\
\hline Albumin (g/l) & & & 0.001 & & & & \\
\hline$<35$ & 69 & 40 & & Reference & & Reference & \\
\hline$>35$ & 137 & 47 & & $0.490(0.321,0.747)$ & 0.001 & $0.590(0.383,0.909)$ & 0.017 \\
\hline VDBP & & & 0.203 & & & & \\
\hline Low & 40 & 13 & & Reference & & & \\
\hline Middle & 145 & 62 & & $1.463(0.805,2.661)$ & 0.212 & & \\
\hline High & 21 & 12 & & $2.013(0.918,4.416)$ & 0.081 & & \\
\hline Total 25(OH)D & & & 0.23 & & & & \\
\hline Low & 59 & 22 & & Reference & & & \\
\hline Middle & 123 & 52 & & $1.180(0.717,1.943)$ & 0.516 & & \\
\hline High & 24 & 13 & & $1.794(0.903,3.563)$ & 0.095 & & \\
\hline
\end{tabular}


Free 25(OH)D

$\begin{array}{lcc}\text { Low } & 19 & 13 \\ \text { Middle } & 72 & 23 \\ \text { High } & 115 & 51\end{array}$

Bioavailable 25(OH)D

$\begin{array}{lll}\text { Low } & 21 & 14 \\ \text { Middle } & 61 & 22 \\ \text { High } & 124 & 51\end{array}$

0.008

Reference

$0.353(0.178,0.699)$

$\mathbf{0 . 5 3 5}(0.290,0.985)$

0.019

Reference

$0.410(0.210,0.803)$

$0.485(0.268,0.877)$

\section{$0.003 \quad 0.241(0.117,0.495) \quad 0$ \\ $0.045 \quad 0.442(0.238,0.819) \quad 0.01$}

Abbreviations: OS: overall survival; HR: hazard ratio; 95\%CI: 95\% confidential interval; Chem: Chemotherapy; 25(OH)D: 25-hydroxyvitamin D; VDBP: vitamin D binding protein; ALB: albumin;BMI: body mass index; L: Low group; M: Middle group; H: High group.

Note: The bold represent that $P$ value was statistically significant.

suppress mitosis by increasing the expression levels of $\mathrm{p} 27 /$ Kip1 and p21/Waf1, inhibiting the activity of cyclin-CDK complex, promoting dephosphorylation of $\mathrm{Rb}$ protein, decreasing the transactivation of $\mathrm{E} 2 \mathrm{~F}$, and then resulting in the tumor cells stagnated in G0/G1 stage [36].

To our knowledge, it was the first study that synthetically investigated the association between total, free, bioavailable $25(\mathrm{OH}) \mathrm{D}, \mathrm{VDBP}$ and the prognosis of patients with stage I-III CRC. The previous studies tended to be more concerned about the total $25(\mathrm{OH}) \mathrm{D}$ or VDBP with CRC outcome separately. Our study could objectively and comprehensively analysis the association among them and our results were then more accurate than the previous. Besides, all samples were collected between 8:00am and 10:00am in ZhongDa hospital, and the plasma samples were all put in -80 degree centigrade environment before collection for assays, which could minimize the side effects of environmental factors on plasma vitamin D levels.

Undeniably, some limitations were also found in our study. Firstly, only 206 patients were enrolled and the small size couldn't represent the whole population which might decrease the power of our results. So further study with more patients included should be conducted. Secondly, the concentrations of 25(OH)D and VDBP were assayed at only one point instead of dynamic monitoring, which might have an important side effect on our results because the plasma $25(\mathrm{OH}) \mathrm{D}$ level would increase by extral multivitamin use, physical activity, and exposure to sunshine. Thirdly, only OS was accessed in this study, which was not able to exclude the influence of cancer unrelated to death. The last but not least, there was a lack of an external validation cohort to test whether actively supplementing vitamin D could increase survival time of CRC patients.

In conclusion, our findings suggested that higher levels of free and bioavailable $25(\mathrm{OH}) \mathrm{D}$ were associated with better OS in I-III stage CRC patients, and free $25(\mathrm{OH}) \mathrm{D}$ was an independent prognostic factor for OS.

\section{MATERIALS AND METHODS}

\section{Study population}

A blanket search was conducted to look for the patients initially diagnosed with CRC from February 2011 to February 2012 in ZhongDa Hospital (Nanjing, Jiangsu, China). All patients were diagnosed through colonoscopy, confirmed with histo-pathological examination and underwent surgery. Patients with any diseases which could have an impact on the metabolism of vitamin D or calcium were excluded from our study, such as serious renal or liver diseases, parathyroid gland diseases, active infection, etc. The present study was approved by the Institution Ethics Commission of ZhongDa Hospital and Southeast University, and informed consents were obtained from all participants.

\section{Information of patients}

We collected the characteristics of all enrolled patients, including sex, age, smoking, drinking, BMI, diabetes, hypertension, treated with surgery or chemotherapy, and the treatment data. In addition, the location of cancer, pathological types, tumor stage were also collected. All information above were obtained from the hospital medical record of ZhongDa Hospital.

\section{Blood sample saving and plasma vitamin $D$ assay}

All samples were collected within seven days before operation from Clinical Laboratory of ZhongDa Hospital. To minimize the effect of ultraviolet or temperature on blood samples, the collecting time was controlled between 8:00am and 10:00am, and the plasma samples were put in -80 degree centigrade environment until assay. The measurement of blood total $25(\mathrm{OH}) \mathrm{D}$ was conducted using direct competitive enzyme-linked immunosorbent assay with the 25(OH)D immunoassay kit (HCB Ltd, Vancouver, Canada). The concentration of plasma VDBP was measured using human VDBP immunoassay kit (R\&D Systems, Minneapolis, USA). Considering the coefficient of variations of inter- and intra-batch about the two kinds of kit, all plasma samples were distributed to triplicate randomly while measuring. The measurement of plasma albumin concentration was also carried out using a bromocresol green dye assay with Beckman automatic biochemical analyzer (AU680) (Beckman Coulter lnc, Tokyo, Japan). After all above steps, free and bioavailable 
$25(\mathrm{OH}) \mathrm{D}$ were calculated from the concentrations of total $25(\mathrm{OH}) \mathrm{D}, \mathrm{VDBP}$ and plasma albumin according to the mathematical equations provided by Bhan et al[37]. All assays were conducted in April of 2014. The methods were carried out according with the approved guidelines.

\section{Follow up}

Patients were followed up regularly dating up to December 10, 2016 or until death according to 7 th edition of the TNM-UICC/AJCC classification for CRC (every 3-6 months for first 2 years, every 6 months for the third to fifth years). The OS was defined as the time from the date of diagnosis to last follow-up or death. Follow-up data for patients were computed from medical records, physical examinations, laboratory examinations or telephone follow-up. All works were conducted by two investigators and any disagreement was solved by discussion.

\section{Statistical analysis}

IBM SPSS Statistical 20.0 (SPSS Inc. Chicago, IL, USA) and X-tile 3.6.1 (Yale University, New Haven, CT, USA) were used for statistical analysis. Differences between high- and low-level group patients were evaluated using the $\chi^{2}$ test or Mann-Whitney $\mathrm{U}$ test. For clinical practice, the continuous variables were changed to categorical variables, and the cutoff values of VDBP, total, free and bioavailable $25(\mathrm{OH}) \mathrm{D}$ were determined by X-tile 3.6.1 (Yale University, New Haven, CT, USA). OS curves were established according to the Kaplan-Meier method and the differences were analyzed by the log-rank test. To identify the independent factors, multivariate cox regression analyses were performed. Variables with a $P$ value less than 0.10 in the univariate cox regression analysis were entered into the multivariate cox regression model using backward conditional method. Two-tailed $P$ values less than 0.05 were considered to be statistically significant.

\section{Abbreviations}

25(OH)D: 25-hydroxyvitamin D; VDBP: vitamin $\mathrm{D}$ binding protein; $\mathrm{CRC}$ : colorectal cancer; OS: overall survival; $1,25(\mathrm{OH})_{2} \mathrm{D}_{3}$ : 1,25 -dihydroxy vitamin $\mathrm{D}_{3}$ VDR: vitamin D receptor; Gc-MAF: Gc protein-derived macrophage activating factor; BMI: body mass index; HR: hazard ratio; 95\%CI: 95\% confidential interval.

\section{Authors' contributions}

LY and $\mathrm{HC}$ designed the experiments. LY, MZ and PP searched for the enrolled patients, collected the detail clinical information of the patients and saved blood samples. LY assayed the concentrations of total $25(\mathrm{OH}) \mathrm{D}, \mathrm{VDBP}$ and plasma albumin, and then calculated the free and bioavailable $25(\mathrm{OH}) \mathrm{D}$ levels. $\mathrm{LY}$ analyzed the data and wrote the paper.

\section{CONFLICTS OF INTEREST}

None.

\section{REFERENCES}

1. Torre LA, Bray F, Siegel RL, Ferlay J, Lortet-Tieulent J, Jemal A. Global cancer statistics, 2012. CA Cancer J Clin. 2015; 65:87-108.

2. Chen W, Zheng R, Baade PD, Zhang S, Zeng H, Bray F, Jemal A, Yu XQ, He J. Cancer statistics in China, 2015. CA Cancer J Clin. 2016; 66:115-32.

3. Ng K, Meyerhardt JA, Wu K, Feskanich D, Hollis BW, Giovannucci EL, Fuchs CS. Circulating 25-hydroxyvitamin $\mathrm{D}$ levels and survival in patients with colorectal cancer. J Clin Oncol. 2008; 26:2984-91.

4. Printz C. High vitamin D levels increase survival rates in patients with metastatic colorectal cancer. Cancer. 2015; 121: 2105 .

5. Song $M$, Nishihara R, Wang $M$, Chan AT, Qian ZR, Inamura K, Zhang X, Ng K, Kim SA, Mima K, Sukawa Y, Nosho K, Fuchs CS, et al. Plasma 25-hydroxyvitamin D and colorectal cancer risk according to tumour immunity status. Gut. 2016; 65:296-304.

6. Jung S, Qian ZR, Yamauchi M, Bertrand KA, Fitzgerald KC, Inamura K, Kim SA, Mima K, Sukawa Y, Zhang X, Wang M, Smith-Warner SA, Wu K, et al. Predicted 25(OH) $\mathrm{D}$ score and colorectal cancer risk according to vitamin D receptor expression. Cancer Epidemiol Biomarkers Prev. 2014; 23:1628-37.

7. Facciorusso A, Del Prete V, Muscatiello N, Crucinio N, Barone M. Prognostic role of 25-hydroxyvitamin D in patients with liver metastases from colorectal cancer treated with radiofrequency ablation. J Gastroenterol Hepatol. 2016; 31:1483-8.

8. Zgaga L, Theodoratou E, Farrington SM, Din FV, Ooi LY, Glodzik D, Johnston S, Tenesa A, Campbell H, Dunlop MG. Plasma vitamin D concentration influences survival outcome after a diagnosis of colorectal cancer. J Clin Oncol. 2014; 32:2430-9.

9. Holick MF, Chen TC. Vitamin D deficiency: a worldwide problem with health consequences. Am J Clin Nutr. 2008; 87:1080S-6S.

10. Christakos S, Ajibade DV, Dhawan P, Fechner AJ, Mady LJ. Vitamin D: metabolism. Endocrinol Metab Clin North Am. 2010; 39:243-53.

11. Wu K, Feskanich D, Fuchs CS, Willett WC, Hollis BW, Giovannucci EL. A nested case control study of plasma 25-hydroxyvitamin D concentrations and risk of colorectal cancer. J Natl Cancer Inst. 2007; 99:1120-9.

12. Bikle DD, Gee E, Halloran B, Kowalski MA, Ryzen E, Haddad JG. Assessment of the free fraction of 25-hydroxyvitamin $\mathrm{D}$ in serum and its regulation by albumin and the vitamin D-binding protein. J Clin Endocrinol Metab. 1986; 63:954-9. 
13. Brown AJ, Coyne DW. Bioavailable vitamin D in chronic kidney disease. Kidney Int. 2012; 82:5-7.

14. Izkhakov E, Somjen D, Sharon O, Knoll E, Aizic A, Fliss DM, Limor R, Stern N. Vitamin D receptor expression is linked to potential markers of human thyroid papillary carcinoma. J Steroid Biochem Mol Biol. 2016; 159:26-30.

15. Kure S, Nosho K, Baba Y, Irahara N, Shima K, Ng K, Meyerhardt JA, Giovannucci EL, Fuchs CS, Ogino S. Vitamin D receptor expression is associated with PIK3CA and KRAS mutations in colorectal cancer. Cancer Epidemiol Biomarkers Prev. 2009; 18:2765-72. doi: 10.1158/10559965.EPI-09-0490.

16. Zhong QL, Huang HY. The research advance of the relationship between vitamin $\mathrm{D}$ binding protein and cancer. Chin J Lab Med. 2014; 37:828-31.

17. Zhang J, Kew RR. Identification of a region in the vitamin D-binding protein that mediates its C5a chemotactic cofactor function. J Biol Chem. 2004; 279:53282-7. doi: 10.1074/jbc.M411462200.

18. Grau MV. Vitamin D, Calcium Supplementation, and Colorectal Adenomas: Results of a Randomized Trial. CancerSpectrum Knowledge Environment. 2003; 95:1765-71.

19. Budhathoki S, Yamaji T, Iwasaki M, Sawada N, Shimazu T, Sasazuki S, Yoshida T, Tsugane S. Vitamin D Receptor Gene Polymorphism and the Risk of Colorectal Cancer: A Nested Case-Control Study. PLoS One. 2016; 11:e0164648.

20. Feldman D, Krishnan AV, Swami S, Giovannucci E, Feldman BJ. The role of vitamin D in reducing cancer risk and progression. Nat Rev Cancer. 2014; 14:342-57.

21. Poynter JN, Jacobs ET, Figueiredo JC, Lee WH, Conti DV, Campbell PT, Levine AJ, Limburg P, Le Marchand L, Cotterchio M, Newcomb PA, Potter JD, Jenkins MA, et al. Genetic variation in the vitamin D receptor (VDR) and the vitamin D-binding protein (GC) and risk for colorectal cancer: results from the Colon Cancer Family Registry. Cancer Epidemiol Biomarkers Prev. 2010; 19:525-36.

22. Hibler EA, Hu C, Jurutka PW, Martinez ME, Jacobs ET. Polymorphic variation in the GC and CASR genes and associations with vitamin D metabolite concentration and metachronous colorectal neoplasia. Cancer Epidemiol Biomarkers Prev. 2012; 21:368-75.

23. Muindi JR, Adjei AA, Wu ZR, Olson I, Huang H, Groman A, Tian L, Singh PK, Sucheston LE, Johnson CS, Trump DL, Fakih MG. Serum vitamin D metabolites in colorectal cancer patients receiving cholecalciferol supplementation: correlation with polymorphisms in the vitamin D genes. Horm Cancer. 2013; 4:242-50.

24. Ying HQ, Sun HL, He BS, Pan YQ, Wang F, Deng QW, Chen J, Liu X, Wang SK. Circulating vitamin D binding protein, total, free and bioavailable 25 -hydroxyvitamin D and risk of colorectal cancer. Sci Rep. 2015; 5:7956.
25. Ng K, Sargent DJ, Goldberg RM, Meyerhardt JA, Green EM, Pitot HC, Hollis BW, Pollak MN, Fuchs CS. Vitamin D status in patients with stage IV colorectal cancer: findings from Intergroup trial N9741. J Clin Oncol. 2011; 29:1599-606.

26. Holick MF. Evolution and Function of Vitamin D. 2003; 164:3-28. doi:

27. Henderson BR. Nuclear-cytoplasmic shuttling of APC regulates beta-catenin subcellular localization and turnover. Nat Cell Biol. 2000; 2:653-60.

28. Bishnupuri KS, Sainathan SK, Bishnupuri K, Leahy DR, Luo Q, Anant S, Houchen CW, Dieckgraefe BK. Reg4induced mitogenesis involves Akt-GSK3beta-beta-CateninTCF-4 signaling in human colorectal cancer. Mol Carcinog. 2014; 53:E169-80.

29. Rosin-Arbesfeld R, Townsley F, Bienz M. The APC tumour suppressor has a nuclear export function. Nature. 2000; 406:1009-12.

30. Pálmer HG, González-Sancho JM, Espada J, Berciano MT, Puig I, Baulida J, Quintanilla M, Cano A, de Herreros AG, Lafarga M, Muñoz A. Vitamin D3promotes the differentiation of colon carcinoma cells by the induction of E-cadherin and the inhibition of $\beta$-catenin signaling. The Journal of Cell Biology. 2001; 154:369-88.

31. Gross MD. Vitamin D and calcium in the prevention of prostate and colon cancer: new approaches for the identification of needs. J Nutr. 2005; 135:326-31.

32. Zhu Y, Mahon BD, Froicu M, Cantorna MT. Calcium and 1 alpha,25-dihydroxyvitamin D3 target the TNF-alpha pathway to suppress experimental inflammatory bowel disease. Eur J Immunol. 2005; 35:217-24.

33. Chen A, Davis BH, Sitrin MD, Brasitus TA, Bissonnette M. Transforming growth factor-beta 1 signaling contributes to Caco-2 cell growth inhibition induced by $1,25(\mathrm{OH})(2) \mathrm{D}(3)$. Am J Physiol Gastrointest Liver Physiol. 2002; 283:G864-74.

34. Ali NA, Molloy MP. Quantitative phosphoproteomics of transforming growth factor-beta signaling in colon cancer cells. Proteomics. 2011; 11:3390-401.

35. Chakrabarty S, Wang H, Canaff L, Hendy GN, Appelman H, Varani J. Calcium sensing receptor in human colon carcinoma: interaction with $\mathrm{Ca}(2+)$ and 1,25-dihydroxyvitamin $\mathrm{D}(3)$. Cancer Res. 2005; 65:493-8.

36. Ylikomi T, Laaksi I, Lou YR, Martikainen P, Miettinen S, Pennanen P, Purmonen S, Syvala H, Vienonen A, Tuohimaa P. Antiproliferative action of vitamin D. Vitam Horm. 2002; 64:357-406.

37. Bhan I, Powe CE, Berg AH, Ankers E, Wenger JB, Karumanchi SA, Thadhani RI. Bioavailable vitamin D is more tightly linked to mineral metabolism than total vitamin $\mathrm{D}$ in incident hemodialysis patients. Kidney Int. 2012; 82:84-9. 